\title{
Descriptions of a new and an unrecorded species of the Heleomyzidae (Diptera) from Japan
}

\author{
Tsunemaru OKADOME \\ Entomological Laboratory, Faculty of Agriculture, Meijo University, Tenpaku-ku, 468-8502 Japan
}

(Received: 30 October 2000; Accepted: 16 April 2001)

\begin{abstract}
Key words: Heleomyzidae, Eccoptomera, new species, Neoleria prominens, new record, Japan
\end{abstract}

\begin{abstract}
A new species, Eccoptomera chibaensis sp. nov. and an unrecorded species, Neoleria prominens (Becker) of the family Heleomyzidae, are described from Japan. The male genitalia of both species are illustrated.
\end{abstract}

\section{INTRODUCTION}

The genus Eccoptomera Loew is a member of the tribe Oecotheini, subfamily Heleomyzinae. It includes 28 species, of which 21 occur in the Palaearctic and 7 in the Nearctic Regions (Gorodkov, 1970; Gill, 1962). However, none of the species were distributed in common in both regions. In Japan only Eccoptomera itoi Okadome was described from Kyushu and Honshu by Okadome (1969). In the present paper, a new species is described under the name of $E$. chibaensis Okadome, sp. nov. from Chiba Prefecture, Honshu, Japan; the genitalia of the male is illustrated and a key to the Japanes species is also presented.

The genus Neoleria Malloch, 1919, belonging to the tribe Heleomyzini, comprises 14 species, of which 10 occur in the Palaearctic, and 7 in the Nearctic Regions (Gorodkov, 1970; Gill, 1962). The author examined a total of 20 males and 5 females of $N$. prominens (Becker, 1897) collected from Hokkaido (Nukabira), Honshu (Saitama and Aichi Prefectures) and Kyushu (Nagasaki Prefecture) in Japan. This is a new record of the genus from Japan.

\section{Genus Eccoptomera Loew}

Eccoptomera Loew, 1862a: 47; 1862b; 127. Type species: Helomyza longiseta Meigen, 1830 (des. Coquillett, 1910).

Key to the Japanese species of Eccoptomera Loew

1. Body testaceous yellow; arista very long; antennae yellowish-orange and one katepisternal bristle .....E. itoi

- Body ash-gray; arista short; antennae black; two katepisternal bristles .... .............. E. chibaensis sp. nov.

\section{Eccoptomera chibaensis sp. nov.} [Japanese name: Chiba-togeasitogehanebae]

(Fig. 1a)

Male. Head: Higher than length; eye nearly round; frons reddish-yellow becoming dull anteriorly; width at level of posterior orbital bristles about 1.3 times the length from anterior ocellus to frontal margin; sides distinctly narrowing anteriorly and frontal setulae dense; ocellar triangle darkened with grayish pruinose; ocellars strong subequal in inner verticals; antennae arising from above $1 / 3$ of head; 

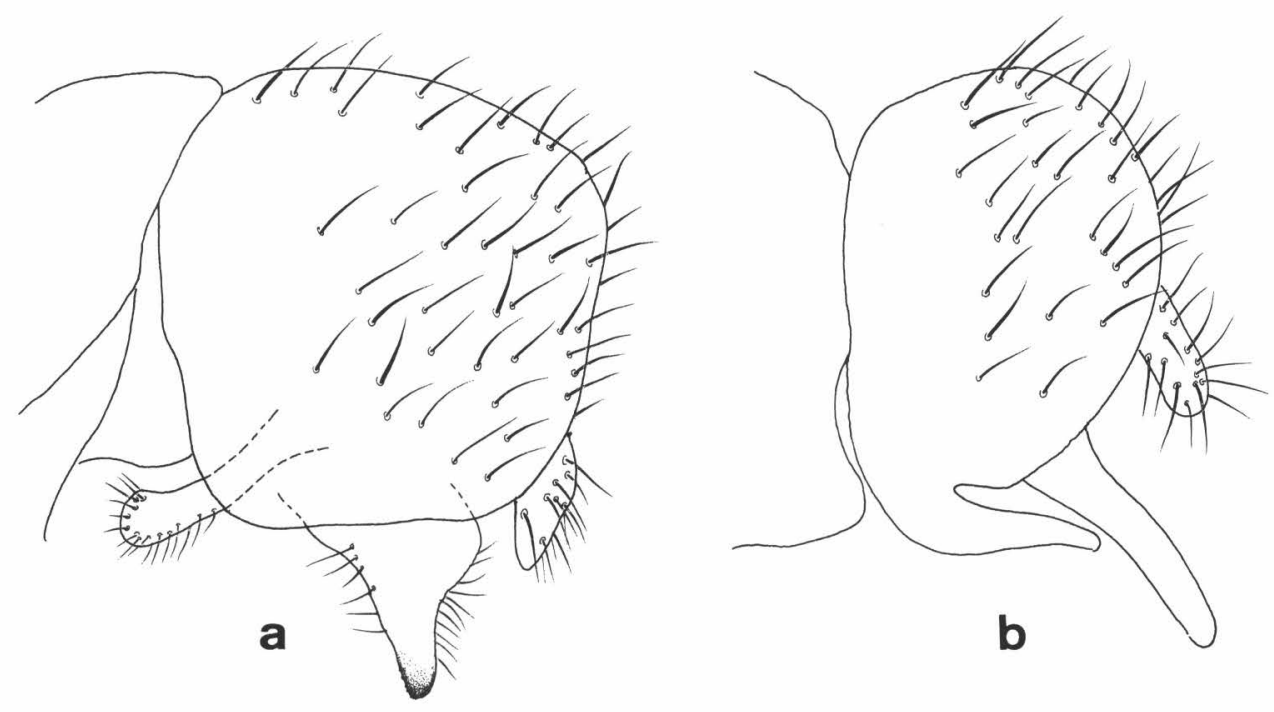

Fig. 1. Male genitalia. —a, E. chibaensis sp. nov.; b, N. prominens.

1st and 2nd segments yellowish-brown, 3 rd segment almost velvety-black, and rounded; arista long, more than 4 times as long as the 3rd antennal segment, shortly pubescent and thickened on basal part; face and cheeks pale yellowish-brown with whitish thin pollen; palpus entirely yellow with about 10 small bristles on ventrally; 1 very long vibrissa and row of about 8 buccal setae present.

Thorax: Mesonotum dull-grey pollinosity; $1+3 d c$ and fine mesonotal setae rising from small dark-brown spots; scutellum bare except for 2 pairs of lateral bristles; pleura paler than mesonotum and slightly tinged with brown mesopleuron; 1 propleural and 2 katepisternal bristles with supplementary hairs.

Legs: Yellowish-brown, except dark brownish femora and 3 apical segments of tarsi; fore femur with a row of 6-7 long bristles on posterodorsal and a row of about 10 long bristles on posteroventral surfaces; mid femora with a row of some short bristles on middle part of anteriorand about 10 small bristles on posteroventral surfaces; hind femora with about 3 bristles on anterodorsal and about 10 small bristles on posteroventral surfaces.

Wing: Glassy-clear; stigma slightly dar- kened; veins mostly pale brown; distance between apices of $\mathrm{R}_{2+3}$ and $\mathrm{R}_{4+5}$ clearly broader than that between apices of $R_{4+5}$ and $M_{1+2}$. Halter pale yellow.

Abdomen: Dull-grey pollinose; hind marginal bristles of epandrium relatively long; genital segments yellowish-brown, small and rounded in lateral view. The genitalia shown in Fig. 1a.

Length: Body $7.0 \mathrm{~mm}$, wing $6.0 \mathrm{~mm}$.

Female. Resembling male, but the hind femur without a row of small bristles on posteroventrally.

Length: Body $8.0 \mathrm{~mm}$, wing $7.0 \mathrm{~mm}$.

Holotype: $\sigma^{7}$, Aobanomori-Park, Chibashi, Chiba-Pref., 16. XII. 1998, R. Kano leg.; Paratypes: $2 \sigma^{\top} 2$ 우, Same data as holotype.

Distribution. Japan (Honshu).

Remarks. This species is similar to the Russian E. promethei Gorodkov, 1966, but is distinguished from it by the height of its genae (about half of that of promethei) and its anterior margin of editum with a few setae or hairs (bare in promethei).

Note. Eccoptomera chibaensis sp. nov. is rare, and its biology is unknown. According to Leister (1967), 42 specimens of a Russian species, E. promethei Gorodkov, were found in the burrows of the longclawed mole-vole, Prometyheomys schaposchnikovi Sat. in Caucasia. 


\section{Genus Neoleria Malloch}

Neoleria Malloch, 1919: 83 c. Type species: Neoleria rotundicornis Malloch, 1919.

Neoleria prominens (Becker, 1897)

[Japanese name: Togari-kenashitogehanebae]

(Fig. 1b)

Tephrochlamys prominens Becker, 1897, Ann. Mus. Zool. Acad. Sci. St. Petersb. 2: 402.

Neoleria prominens (Becker): Gill, 1962, Proc. U. S. Natl. Mus., 113: 551. -Gorodkov, 1984, Catalog. Palae. Reg., 10: 22.

Male. Head: Dark-gray higher than length; frons reddish-yellow becoming dull anteriorly; width at level of posterior orbital bristles about 1.8 times the length from anterior ocellus to frontal margin; frontal sides slightly narrowing anteriorly and setulae rather dense; ocellar triangle darkened, grayish pruinose; ocellar bristle strong; orbit yellowish-brown with whitish pruinose; antennae reddish-yellow, arising from about the middle of head; the 3rd segment oval and darkened; arista brownish-gray to black, pubescent; frontal lunule and face reddish-yellow with whitish thin pruinosity; 1 very long vibrissa and a row of about 6 buccal setae present.

Thorax: Mesonotum ash-gray to black; 1 $+3 d c$ and fine mesonotal setae rising from small dark-brown dots; humerus and edges of pleura grayish-brown to dark; scutellum bare on dorsum, except for usual lateral bristles.

Wings: Hyaline membrane, slightly clouded along the costal area; veins yellowish-brown; costal spines rather long, about twice the width of the costa. Halter entirely pale yellowish-brown.

Legs: Yellowish-brown except darkened fore femur and distal ends of tibia and tarsi; fore femur posterodorsally with a row of about 10 long bristles and posteroventrally with a row of about 5 short bristles; mid femur with some short bris- tles on anterior surface and a row of about 10 short bristles antero- and posteroventral surfaces; hind femur with a row of about 10 short bristles on antero- and posteroventral surfaces.

Abdomen: Dark ash-gray, conspicuously becoming yellowish-orange distally; posterior marginal bristles of tergites $2-5$ well developed; epandrium pale yellow and rounded in lateral view. Male genitalia shown in Fig. 1, b.

Length: Body $4.0 \mathrm{~mm}$, wing $5.5 \mathrm{~mm}$.

Female. Resembling male, but rows of short bristles on antero- and posteroventral surfaces of mid and hind femora are inconspicuous, and the setulae of the legs are uniformly weakly.

Length: Body $5.5 \mathrm{~mm}$, wing $6.0 \mathrm{~mm}$.

Specimens examined. [HOKKAIDO] 10', Fujikawa, 19. VII. 1967, T. Saigusa leg.; [HONSHU] 10 $10^{7}$ Mikajima, Tokorozawa, Saitama Pref., 2-16. III. 1990, H. Mitsui leg.; 2ð', Nissin, Aichi Pref., 21. III. 1971, K. Yamagishi leg.; [KYUSHU] 16주 5우, Mt. Gokahara, Hegi (500 m), Nagasaki Pref., 20. III. 1992, H. Kurahashi leg.

Distribution. Japan (Hokkaido, Honshu and Kyushu); Nearctic.

Remarks. According to Gill (1962), this species is similar to $N$. inscripta (Meigen, 1830) known from the Holarctic region. $N$. prominens differs from inscripta by having the following features: antennae darkened, especially 3rd segment becoming blackish; arista brown to black; mesonotum ashgray to black; $d c$ becoming gradually weaker anteriorly; legs reddish-brown to dark brown; abdomen dark ash-gray.

Note. This species has been found from the nest of a glaucous gull [Linscripta arus hyperboreus Gunners; Charadriformes, Laridae] (Collin, 1923), from the carcass of an Eskimo dog (Weber, 1954), and from a garbage dump (Gill, 1962). The species is known as a common synanthropic fly, and the larvae are reared in latrines (Gorodkov, 1970). In Japan, most of the adult flies examined were attracted to a decayed meat trap. 


\section{ACKNOWLEDGEMENTS}

I am grateful to the late Dr. R. Kano, Professor Emeritus of Tokyo Medical and Dental University, Dr. T. Saigusa, Professor Emeritus of Kyushu University, Dr. H. Kurahashi, National Institute of Infectious Diseases, Dr. K. Yamagishi, Meijo University, and Mr. H. Mitsui in Tokyo, for their kind gift of materials to work on the heleomyzid fly.

\section{REFERENCES}

Becker, T. 1897. Beitrage zur Kenntnis der Dipterenfauna von Nowaja-Semlja. Ann. Mus. Zool. Acad. Sci. St. Pétersbourg, 2: 402.

Collin, J. E. 1923. Diptera (Orthorrhapha Brachycera and Cyclorrhapha) from Spitsbergen and Bear Island. Results of the Oxford University expedition to Spitsbergen, 1921, Ann. Mag. Nat. Hist., Ser. 9, 11: 121 .

Coquillett, D. W. 1910. The type-species of the North American genera of Diptera. Proc. U. S. Natl. Mus., 37: 499-647.

Gill, G. D. 1962. The heleomyzid flies of America north of Mexico (Diptera: Heleomyzidae). Proc. U. S. Natl. Mus., 113: 495-603.

Gorodkov, K. B. 1966. The new species of the Family
Heleomyzidae (Diptera) from the Asiatic part of Palaearctic. Tr. Zool. Inst., Leningr., 37: 240-257 (In Russian).

Gorodkov, K. B. 1970. 80. Family Helomyzidae (Heleomyzidae). In: Checklist of Insects of the European Part of the USSR 5 (ed. Bei Bienko), pp. 306-325, Leningrad (In Russian).

Gorodkov, K. B. 1984. Family Heleomyzidae. In: Catalogue of Palaearctic Diptera (ed. Soós, A. and Papp, L.). pp. 15-45, Akadémiai Kiadó, Budapest.

Leister, J. A. 1967. The fauna of insects in the Burrows of the Caucasian endemic, long-clawed molevole. Entomol. Obozr, 46: 185-200 (In Russian).

Loew, H. 1862a. Über die europäischen Helomyzidae und die in Schlesien vorkommenden arten derselben. Z. Entomol. Breslau., 13: 1-80.

Loew, H. 1862b. Novae Helomyzidarum in Europa viventium species. Wien. Entomol. Mschr., 6: 126128.

Malloch, J. R. 1919. The Diptera (excluding the Tipulidae and Culicidae). Rep. Can. Arct. Exped., 19131918, 3C: 83-84.

Meigen, J. W. 1830. Systematische Beschreibung der bekannten europäischen zweiflügeligen Insekten. 6: 45-61, Schulz, Hamm.

Okadome, T. 1969. Descriptions of three new heleomyzid flies from Japan (Diptera: Heleomyzidae). Kontyû, 37: 399-402.

Weber, N. A. 1954. Arctic Alaskan Diptera. Proc. Entomol. Soc. Washington, 56: 86-91. 